\title{
What Do University Students Think About The Roles Of Intellectuals? Empirical Findings of a Hungarian Analysis
}

\author{
Veronika Bocsi \\ Associate professor, University of Debrecen, Faculty of Education for Children and Special Educational Needs, \\ Hungary
}

\begin{abstract}
There is a debate in the field of social sciences about the role of intellectuals. More possible directions can be distinguished: professional, intelligentsia and public intellectual. These types have got their own historical, geographical and political backgrounds but if we regard universities as places in which intellectuals are trained we have to highlight the importance of higher education at the same time. Despite the wide theoretical background empirical findings have narrowly been known. In this paper quantitative method was used and we try to analyze what university students think about the role components of intellectuals. Our database came from 2017 from a nationwide Hungarian student analysis $(\mathrm{N}=1502)$. We created our own made question-block with 18 items and undergraduates had to scale these items which belong to the role components of intellectuals. We can state that students have got a mixed pattern in the analyzed field. The components of professional role are strong and this fits into the national educational policies - but other elements are significant too. The features of classical intellectual habitus are strong as well (general knowledge, white collar work etc.), but the components of public intellectuals and macro-level aims have less importance.
\end{abstract}

Keywords: higher education, intellectuals, professional roles, students

\section{Introduction}

We have to regard the system of higher education as the place of students' socialisation process and in this framework several elements of knowledge (vocational and general at the same time), norms, values or components of behaviour can be transmitted (Weidman, 2006; Kaufman \& Feldman, 2004; Graham, 2005). The wider and formal system of this process is the organisation of universities with their own manifest aims and rules. Nevertheless, a lots of segments of this process may be hidden - e.g. the effects of peer-networks, leisure time activities and cultural or social events. And we have to beware at the fact that the students are not passive participants in this process because they can form the climate of institutions too and they have got their own effects on lecturers at the same time. To sum up, the process of students' socialisation is complex and not single-line. 
Naturally the most important aim of higher education to transmit the elements of vocational skills and knowledge, but students have to regarded as would-be intellectuals. From this aspect the university is a place where they can learn those elements which belong to their later social and vocational roles. Scientific literature distinguished the possible role types of intellectuals and these belong to specific geographical location, historical periods, disciplines or political framework (Fónai, 1995). The notion of 'professional' emerged in the 19. centuries due to the modernisation process, it contains mainly vocational knowledge and elements, in the case of 'public intellectual' the public or critical functions get importance and these persons can from and take part in public debates, and the 'intelligentsia' belongs to the semi-peripheral or peripheral situation (e.g. Eastern Europe too), the position of role modelling and ideas. The situation of Hungary is specific due to the semi-peripheral situation, the effects of earlier and current political situation and the utilitarian emphases of actual educational policy.

The birth of the universities in Europe stayed in close relationship with the emerge of intellectuals' social group in the Middle Ages (Goff, 1993), but over the centuries the institutions and the outside contexts were changed too. The approach which distinguishes the elitist and mass higher educational system is frequently used but a little bit simplifying. The universities always apply the path of social mobility (with different efficiency) and the current systems have been differentiated. Moreover, the possible patterns of intellectual roles were changed too -due to the internet-usage and mediatisation (Fleck et al., 2006; Davis, 2006) which transform the 'public intellectual roles' and the attitude to knowledge, the changing landscape of high culture consumption (Peterson \& Kern, 1996), the effects of postmodern theories (Bauman, 1987), and naturally the political systems at all the times (Auer, 2006; Ettrich, 2007). This last context shapes the possibilities of critical and public functions of intellectuals in depths.

In this paper we would like to analyse that such conceptions students have about intellectual roles and we try to reveal what factors can form these conceptions. To reveal these patterns a question-block with 18 items was created by us and it was tested during a nationwide Hungarian student analysis in 2017. These items belong to the possible role components of intellectual life: professional, public intellectual and intelligentsia. The novelty of this paper is the quantitative methodological approach and the relevance is the transformation of higher educational institutions due to the educational expansion, the marketization (Bok, 2004) and the increase of vocational and utilitarian expectations (Panton, 2005). We suppose that with the help of our empirical findings the patterns of later Hungarian intellectuals may be revealed. Means, principal component analysis and linear regression model were used, and the principal components were identified with the help of rolecomponents. We try to reveal a wide range factors which can form the patterns of intellectual roles (gender, parental educational level, economic capital, the type of settlement, the type of training course, religiosity and disciplines).

\subsection{The transformation of universities}

Earlier we have named some external elements which can form the conceptions about intellectual roles but we have to focus on the transformation of universities in first line. This transformation is a complex notion and social demands, financial causes, the market situation in higher educational system, the central educational policies and other factors shape this 
current landscape of higher educational system. Naturally we can't give a detailed picture about this whole process but some elements will be described.

Our first starting point is the evolve of mass higher educational system which can form the possibilities and tasks of higher education in the field of intellectuals' training. This process rises the rate of so called first-generation students (Pike \& Kuh, 2005) who do not bring from home those patterns, norms and habitus-components which belong to the intellectual life. From these students the universities are not a familiar space but a strange world. The tasks of some universities in this situation will be changed because they have to install such elements of knowledge and skills whose presence is axiomatic in the elitist segment of higher education. This change can shape the cultural climate of universities (cultural events, communication, language usage etc.) and the contents of planned effects from the direction of institution too. Panton (2005) highlighted that universities have to fit into students' demands and this phenomenon can be observed in this field too. Integration into university along social events and peer-group networks does less fit into high culture consumption or the habitus of middle class.

Other important factor belongs to the framework of universities' working method. This transformation summed by Fitzgerald (2012) and Bok (2004) and its contains are the following: marketization, closer relationship between industry and universities, the dominance of applied research projects, the regarding students as consumers, quality insurance and the quantification of the whole teaching process (Naidoo, 2005). This shift created a more controlled institutional system in which some intellectual functions became less relevant (critical or public function, the independence in the field of research or ideas etc.). Some disciplines fit into this new framework to a lesser extent and this disadvantageous situation reduce the importance of arts, fine arts or social sciences. The scientific literature (Reuben, 1996) highlighted that some elements of intellectual roles stays in close relationship with these disciplines (moral statements, ideas etc.).

The transformation of student body has been already described. Other very important factor is the expectation of students toward universities -which contents students would like to get inside the institution and which skills to learn. Specific literature highlighted that these expectations became more utilitarian (Veroszta, 2010) and the demands belongs increasingly to practical skills (Lähteenoja \& Pirttilä-Backman, 2005). This shape moves students from the theoretical contents of the given disciplines, the teaching method of lectures and such courses which stay in close relationship with general knowledge or elements beyond students' narrower profession. This transformation can reduce the chance of dialogues or debates in the classroom with lecturers or peers about public issues too. In the phase of expansion the research activity of undergraduates has changed - these skills became less parts of their demands - they simply do not need have these skills in earlier level. The diversification of the higher educational system generates huge gaps among institutions and can reduce the research-oriented attitude in the 'lower' segment of universities (in these institutions the rate of first-generation students is higher). These shifts are important for us because the creating of ideas, research products or the transmission of these elements toward society can be the part of intellectual roles. If the aim of these undergraduates is the fast integration into labour-market the useful contents will be for them more practical and vocation-oriented. This shift can be linked to the 'professional' role. 
Naturally the situation of lecturers was changed too and this transformation has come to forefront of debates (Hoenig, 2017; Enders, 2009; Scott, 2005, White, 2012). The work of lecturers becomes more complex (teaching, research, administration, to taking part in applications etc.) and in the lower segments of higher education lecturers have to undertake such task which rather belong to social work or psychology (Bocsi, 2019). Some empirical findings reported the higher level of work-load after the Millennium and a higher level of alienating (Barnett, 2000). Due to the audit and quality insurance system, the higher importance of scientometrics and the claim of transparency in teaching process the independence and autonomy seems to be reducing. The applied research projects can channel the topics of research projects. This shift can separate the teaching from the research, and the controlled circumstances may decrease the "public intellectual" functions of lecturers.

\subsection{Hypotheses}

According to the scientific literature the following hypotheses were formulated by us:

H1. We suppose the highest positions of "vocational" items and the role model of 'professional' due to the utilitarian expectations of students and the current educational policy (Bok, 2004; Fitzgerald, 2012). In this phase of empirical analysis the means of items will be described.

$\mathrm{H} 2$. We suppose the strong effects of disciplines in the linear regression model according to Bok (2004). McInnis (2010) states that the disciplines have their own norms and rules (Neave, 2009) which create different organisational cultures, too. We assume that these organizational cultures contain the different patterns of intellectual roles. The dependent variables will be the principal components in the regression models. and the independent variables are the following: socio-demographic variables (gender, economic capital, parental education educational level, the type of religiosity), the type of training course and disciplines.

\section{Methods}

Our empirical data come from a nationwide quantitative research project carried out in Hungary ("Family and Career" project - led by Ágnes Engler in 2017). The aim of the research project was to describe the students' conceptions of gender roles, child-rearing and students' parenting (Engler, 2018). The question block dealing with intellectual roles is found on the last page of the questionnaire. The number of respondents was 1502. The respondents came from 11 higher educational institutions in Hungary (three from Budapest and seven from other cities: Eötvös Loránd University, Semmelweis University, University of Debrecen, Óbuda University, University of Nyíregyháza, University of Szeged, University of Pécs, Eszterházy Károly University, Szent István University, Debrecen Reformed Theological University, and Kaposvár University).

The type of the sampling was stratified and the aspects of the sampling were the following: regions of the country, the size of the institutions and disciplines. The population consists of full time students in BA, MA and combined courses, i.e., courses combining a BA and an MA programme (except first year students in BA and combined courses). The leaders of the research project chose the institutions on the basis of the disciplines offered by the universities, and the locations of the universities. Law and economics are classified as social 
sciences, and informatics as engineering. Medicine also included nursing. In the case of teacher training courses, disciplines were determined according to the field of study (e.g., a literature teacher was classified as studying humanities). This encoding was used during the whole research project.

We have created a block of questions with 18 items which discover the role components of intellectuals. These items were based on the literature (definitions of intellectuals, the possible roles (professionals, public intellectuals, etc.)) and we tried to cover every segment of the intellectual life and roles concerned. The respondents evaluated the items on a fourgrade scale (e.g., expertise, analysis of social notions, intellectual independence, high culture activities, preservation of national culture, benevolence and beauty etc.).

The independent variables were gender, the type of the settlement, the parental educational level (mother and father separately), objective economic capital, ${ }^{1}$ the type of training course (bachelor, master, combined) and scientific fields in linear regression model. Gender was used as a dichotomous variable ( $1=$ man, $0=$ woman). The parental educational level was used as a continuous variable (with the number of completed years of education - most parents attended higher education before the Bologna system, so completing a college course was coded as 16 years of education, and a university course as 17.). Dummy encoding was used by the type of settlement (reference category: smaller cities, other options: capital city, county town, village), disciplines (reference category: agronomy, other options: humanities, social sciences, science, engineering, fine arts, theology and medical studies), religiosity (reference category: uncertain, other possibilities: non-religious, 'I am religious and I follow the rules of my church' and 'I am religious on my own way') and the type of course (reference category: bachelor course). We decided to use a religiosity as an independent variable because we would like to separate the effect of theological training courses from the effect of religiosity.

\section{Results}

\subsection{Participants}

The proportion of women in the sample was 56\%. Most respondents attended bachelor's courses (10 percent were in master's courses or were senior students from combined courses). If we go through the subsamples of the disciplines, engineering, medicine, and humanities are the most populous subsamples $(\mathrm{N}=388,277$, and 266, respectively). The second lowest number is theology $(\mathrm{N}=55)$. The number studying agriculture was too low to use the data $(\mathrm{N}$ $=26$ ), so during the linear regression model the latter subsample was used as the reference category. ${ }^{2}$ The mean of the objective economic capital index was $7.26(S D=1.649)$. Overall, 10 items were used with a maximum value of 10 and a minimum of 0 in the whole sample $(0=$ not possessed by the household, $1=$ possessed by the household $)$. Some $30 \%$ of fathers

\footnotetext{
${ }^{1}$ Components of the index: Does the family have its own apartment or house, cottager or plot, a flatscreen television, a personal computer or laptop with broadband internet access at home, a tablet or e-book reader, mobile internet (on the phone or computer), a dishwasher, an air-conditioner, and a smartphone or car?

2 The rate of the subsamples were the following: $17.7 \%$ - Arts, $15.5 \%$ - Social Sciences, $8.2 \%$ - Science, 26.5\% - Engineering, 18.4\% - Medicine, 7.3\% - Fine arts, 3.7\% - Theology and 1.7\% - Agronomy.
} 


\section{iorhs}

\section{4th International Conference On Research In HUMANITIES \& SOCIAL SCIENCES}

and $38 \%$ of mothers have a degree. The proportion of low-educated parents (below graduation) is $27.4 \%$ for fathers and $16.2 \%$ for mothers. Of all students, $9.4 \%$ come from the capital city, $19 \%$ from a county seat, $45.8 \%$ from a smaller city, and $25.5 \%$ from villages and farms. $67.6 \%$ attends a bachelor training course, $11.1 \%$ master training course and $20.5 \%$ takes part in undivided form (training of lawyer, doctor and teacher). 13.7\% said that 'I am religious and I follow the rules of my church', $6.9 \%$ is uncertain, $28.2 \%$ is non-religious and $39.9 \%$ said that 'I am religious on my own way'.

\subsection{Empirical findings}

The reliability of the block of questions was tested (the Cronbach alpha score was .812 and the lowest score among the items was .792, so every item was retained). Our first step was to analyse the mean of the items (Table 1).

Table 1. The students' conceptions about intellectual roles $(N=1502$, means of four-grade scales $)$

\begin{tabular}{|c|c|c|}
\hline & $M$ & $S D$ \\
\hline Competence in the field of your own discipline & 3.47 & 0.65 \\
\hline Benevolence and beauty & 3.33 & 0.73 \\
\hline General knowledge & 3.30 & 0.67 \\
\hline Degree, adequate educational level & 3.28 & 0.78 \\
\hline White-collar work & 3.22 & 0.72 \\
\hline $\begin{array}{l}\text { Being a role model. Improving the local community and } \\
\text { society. }\end{array}$ & 3.14 & 0.83 \\
\hline Independence (from institutions and politics) & 3.11 & 0.82 \\
\hline Knowledge of specialist literature & 3.00 & 0.77 \\
\hline $\begin{array}{l}\text { Spreading and using research findings. Improving } \\
\text { society. }\end{array}$ & 2.99 & 0.79 \\
\hline Preservation of national identity and culture & 2.95 & 0.84 \\
\hline Consumption of high culture & 2.86 & 0.81 \\
\hline $\begin{array}{l}\text { Contribution to and spreading of European and/or global } \\
\text { culture. Setting up international relationships. }\end{array}$ & 2.80 & 0.84 \\
\hline Mediation between social groups or pressure groups & 2.78 & 0.83 \\
\hline Analysing and criticizing social phenomena & 2.77 & 0.88 \\
\hline $\begin{array}{l}\text { Taking part in public affairs and fulfilling public } \\
\text { functions }\end{array}$ & 2.74 & 0.77 \\
\hline Creating scientific or artistic products & 2.56 & 0.90 \\
\hline $\begin{array}{l}\text { Participating in public debates and having a presence in } \\
\text { the media }\end{array}$ & 2.43 & 0.92 \\
\hline $\begin{array}{l}\text { Controlling authority, criticizing and taking part in a } \\
\text { demonstration }\end{array}$ & 2.30 & 0.96 \\
\hline
\end{tabular}

Source: own table 


\section{iorhs}

\section{4th International Conference On Research In HUMANITIES \& SOCIAL SCIENCES}

With the help of the items principal components were identified. During this process 11 items were saves (KMO: 0,714, saved information: 59.6\%). Table 2. shows these patterns (criticism and public life, classical, moralist and national and knowledge-oriented components).

Table 2. The principal components about intellectual life $(N=1502$, principal component method, varimax rotation)

\begin{tabular}{|l|c|c|c|c|}
\hline & $\begin{array}{c}\text { criticism } \\
\text { and public } \\
\text { life }\end{array}$ & classical & $\begin{array}{c}\text { moralist } \\
\text { and national }\end{array}$ & $\begin{array}{c}\text { knowledge- } \\
\text { oriented }\end{array}$ \\
\hline Competence in the field of your own discipline &,- 168 &, 251 &, 039 & $\mathbf{7 2 1}$ \\
\hline General knowledge &, 128 &, 090 &, 117 & $\mathbf{7 8 3}$ \\
\hline $\begin{array}{l}\text { Participating in public debates and having a presence in } \\
\text { the media }\end{array}$ & $\mathbf{, 6 5 9}$ &,- 138 &, 216 & $\mathbf{, 3 9 5}$ \\
\hline $\begin{array}{l}\text { Taking part in public affairs and fulfilling public } \\
\text { functions }\end{array}$ & $\mathbf{, 7 7 4}$ &,- 061 &, 083 &, 000 \\
\hline Knowledge of special literature &, 113 & $\mathbf{, 5 8 0}$ &, 023 &, 298 \\
\hline White collar work &, 010 & $\mathbf{6 5 5}$ &, 161 &, 200 \\
\hline Independence (from institutions and politics) &, 022 & $\mathbf{, 7 1 9}$ &, 109 &,- 043 \\
\hline Analysing and criticizing social phenomena & $\mathbf{6 2 2}$ &, 372 &, 195 &,- 079 \\
\hline Benevolence and beauty &,- 053 &, 226 & $\mathbf{7 9 4}$ &, 086 \\
\hline Preservation of national identity and culture &, 157 &, 072 & $\mathbf{8 0 9}$ &, 088 \\
\hline $\begin{array}{l}\text { Controlling authority, criticizing and taking part in a } \\
\text { demonstration }\end{array}$ & $\mathbf{, 7 4 3}$ &, 138 &,- 206 &,- 089 \\
\hline
\end{tabular}

Source: own table. Numbers above .30 are in bold.

In our last step was the running of the linear regression model in which the dependent variables were the principal components. Table 3. shows the empirical findings of three models.

Table 3. The regression model of conceptions about intellectual roles (beta values, $p \leq 0,05$, sig. $=0,000: * * *$, sig. between 0,001 and $0,0=* *$, sig between 0,01 and $0,05=*$ )

\begin{tabular}{|l|l|l|l|l|}
\hline & $\begin{array}{c}\text { criticism } \\
\text { and } \\
\text { public life }\end{array}$ & classical & $\begin{array}{c}\text { moralist } \\
\text { and } \\
\text { national }\end{array}$ & $\begin{array}{c}\text { knowledge- } \\
\text { oriented }\end{array}$ \\
\hline Gender (0=man. 1=woman) & $-.119^{* *}$ & & $.111^{* *}$ & \\
\hline Economic capital (with index) & & & & \\
\hline $\begin{array}{l}\text { The type of the training course (reference: bachelor } \\
\text { course) }\end{array}$ & & & & \\
\hline Master's course & & & & \\
\hline Combined course & & & & \\
\hline
\end{tabular}




\section{iorhs}

4th International Conference On Research In HUMANITIES \& SOCIAL SCIENCES

\begin{tabular}{|c|c|c|c|c|}
\hline The type of settlement (reference: smaller city) & & & & \\
\hline Village & & & & \\
\hline County town & & & & \\
\hline Capital city & $.088^{*}$ & & & $-.114 * *$ \\
\hline Parental educational level & & & & \\
\hline $\begin{array}{l}\begin{array}{l}\text { Fathers' educational level (with completed years of } \\
\text { education) }\end{array} \\
\end{array}$ & & $.092 *$ & & \\
\hline $\begin{array}{l}\text { Mothers' educational level (with completed years of } \\
\text { education) }\end{array}$ & & & & \\
\hline Religiosity (reference category: uncertain) & & & & \\
\hline 'I am religious and I follow the rules of my church.' & & &, $177 * *$ & \\
\hline 'I am religious on my own way' & & & & \\
\hline Non-religious & & & & \\
\hline Disciplines (reference category: Agronomy) & & & & \\
\hline Humanities & $.271 * *$ & $.226 * *$ & & \\
\hline Social sciences & $.226 * *$ & & & \\
\hline Science & & & & \\
\hline Engineering & & $.188^{*}$ & & \\
\hline Medical Studies & $.215^{* *}$ & & & \\
\hline Fine arts & $.137 *$ & & & \\
\hline Theology & & & $.131 *$ & \\
\hline Adj. $R^{2}$ & .290 & .196 & .301 & .223 \\
\hline
\end{tabular}

Source: own table

\section{Discussion}

On the basis of our empirical findings we can model the students' conceptions of intellectual roles. It is clear that it is a mixed pattern in which the professional and classic intellectual elements ('Benevolence and beauty', 'General knowledge') are dominant. The items of criticism, the elements of public intellectual life and the macro-level effects are less important. The moral component ("Benevolence and beauty") seems to be far from the postmodern attitude, and the low level of critical and public intellectual functions can be explained by a dissonant relationship of Hungarian young people with policy and politics. The location of the effects on intellectuals has only been the narrow environment of the individual (see the position: "Being a role model. Improving the local community and society"). According to the literature, we supposed the dominance of professional elements based on the theories which analyse the transformation of universities. The first hypothesis was verified but our empirical findings show us a more diverse picture. Moreover, the item of 'Knowledge of specialist literature' has got a less importance.

According our second hypothesis we suppose the most dominant effects of disciplines in the regression models. Before this step of analysis principal components were identified. We 
have to see that the patterns of factors are not absolutely fit into theoretical background of intellectual roles. The first factor is similar to the notion of 'public intellectual' but the others shows us that theoretical categories are not palpable with the help of our empirical results. The vocational items are separated from each other, and the moral and national elements are interlocked. The pattern of second factor (classical) seems to similar to the notion of freefloating intellectuals (Mannheim, 1993) but it contains 'The knowledge of special literature' too. The conception of third factor (moralist and national) colligates two traditional elements. According to the empirical findings the effects of disciplines seems to be important in the case of some factors (but not in the case of every principal components) so this hypothesis was only partially verified.

Some socio-cultural variable can form the contents of intellectual roles: women seem to be a wider distance from 'public intellectual' roles. The churchly religiosity stays in close relationship with 'moral and national' factor and the higher educational level of fathers promotes 'classical' conceptions (perhaps the fathers' educational level links tighter to the habitus and prestige of middle class than mothers'). The public elements are not typical in the case of theology, engineering and science. The theological trainings can form 'moral and national' attitude (while the religiosity has got a similar effect as well). The effects of engineering require furthers investigations -perhaps with qualitative techniques this relationship can be described. The connection between humanities and 'classical' conception seems to be logic.

\section{Conclusion}

The most important edification of our research is the mixed patterns of students about intellectual roles. Although the transformation of universities and the educational policy support the presence of 'professional' elements, and the expectations of undergraduates connects with labour-market oriented attitude the ideas of the intellectual roles contains various elements. The macro-social aims seem to be less important and this result may predict a standoff from public cases of future intellectuals in Hungary. We can interpret this result with the help of special features of political socialization process in Eastern Europe (Szabó, 1990) or the relative passive attitude of Hungarian youth (Oross, 2013). The different norms and beliefs of the disciplines can be verified too and we can analyse these special elements with the regression model. It is clear-cut that students in some fields are not involved in public cases and debates but the traditional and moral elements are not typical too -except the theology. The change of women' rate in the case of a given profession can form the later public behavior of intellectuals (due to the effects of gender in the case of first and third principal components).

In this analysis we tried to reveal the conceptions of intellectual roles of university students with quantitative techniques and compare our empirical findings with theoretical frames and the current situation of universities. Naturally this analysis is rather interpretable as pilot study and the testing of the first version of an incriminated question-block. We are planning the usage of qualitative analysis later to reveal the emerging of these patterns and the effects of higher educational institutions. We hope that with the help of interviews we can focus on the specific subcultures inside the universities and we can reflect on the process of conceptions' evolving too. 


\section{iorhs}

\section{4th International Conference On Research In \\ HUMANITIES \& SOCIAL SCIENCES}

\section{Limitations}

Our research has got several limitations. Firstly, the block of questions we used was our own creation, so we do not have the chance for international comparison. Secondly, other scholars might have used other items during the operationalisation. This was a nationwide analysis but the Hungarian situation is special due to the semi-peripheral position of the country and its post-socialist features - nonetheless, the empirical findings can be more relevant in Central and Eastern Europe.

\section{Acknowledgment}

This article was created with the support of the János Bolyai Research Scholarship of the Hungarian Academy of Sciences and it was also supported by the ÚNKP-20-5 New National Excellence Program of the Ministry of Human Capacities.

\section{References}

Auer, S. (2006). Public Intellectuals: East and west. Jan Patocka and Václav Havel in contention with Maurice Merleau-Ponty and Slavoj Zizek. In. Fleck, Ch., Hess, A. and Lyon, S. E. (Eds.): Intellectuals and Their Public. Perpectives from Social Sciences. London: Rutledge, pp. 89-105.

Barnett, R. (2000). Supercomplexity and the curriculum. Studies in higher education, 25. no. 3. pp. $255-265$.

Bauman, Z. (1987). Legislators and Interpreters: On Modernity, Post-Modernity and Intellect. Cambridge: Polity Press.

Bocsi, V. (2020). Hallgatói szocializáció - oktatói szemmel. Különleges BánásmódInterdiszciplináris folyóirat, vol. 6. no. 2. pp. 19-33.

Bok, D. (2005). Universities in the Marketplace. Princeton and Oxford: Princeton University Press.

Davis, H. (2006). Conclusion. Revisiting the concept of the public intellectual. In. Fleck, Ch., Hess, A. and Lyon, S. E. (Eds.): Intellectuals and their Public. Perspectives from Social Sciences. London: Rutledge, pp. 261-269.

Engler, Á. (Ed.) (2018). Család és karrier. Egyetemi hallgatók jövőtervei. Debrecen, HU: CHERD.

Enders, J. (2009). Introduction. In. Enders, J., De Weert, E., and de Weert, E. (Eds.). (2009). The Changing Face of Academic Life: Analytical and Comparative Perspectives. Basingstoke, UK: Palgrave - Mcmillan. pp. 1-12.

Ettrich, F. (2007). Szabadon lebegő értelmiség és új osztály. Világosság, vol. 48. no. 7-8. pp. 175-190. 


\section{iorhs}

\section{4th International Conference On Research In}

HUMANITIES \& SOCIAL SCIENCES

Fitzgerald, T. (2012). Tracing the fault lines. In. Fitzgerald, T., White, J. and Gunter, M. H. (Eds.): Hard Labour? Academic Work and the Changing Landscape of Higher Education. Bingley, UK: Emerald Group, pp. 1-22.

Fleck, Ch., Hess, A. and Lyon, S. E. (eds.) (2006). Intellectuals and their Public. Perpectives from Social Sciences. London: Routledge.

Graham, G. (2005). The Institution of Intellectual Values: Realism and Idealism in Higher Education (Vol. 5). Exeter, UK: Imprint Academic.

Fónai M. (1995). Értelmiség, értelmiségi funkciók és szerepek - egy regionális kutatás konzekvenciái. Budapest: Társadalomkutatási Informatikai Egyesülés.

Hoenig, B. (2017). Europe's New Scientific Elite: Social Mechanisms of Science in the European Research Area. London, UK: Taylor \& Francis.

Kaufman, P., \& Feldman, K. A. (2004). Forming identities in college: A sociological approach. Research in Higher Education, vol. 45. no. 5. pp. 463-496.

Lähteenoja, S., \& Pirttilä- Backman, A. M. (2005). Cultivation or coddling? University teachers' views on student integration. Studies in Higher Education, vol. 30. no. 6. pp. 641-661.

Le Goff, J. (1993). Intellectuals in the Middle Ages. Oxford, GB: Wiley-Blackwell.

Mannheim, K. (1993). The sociology of intellectuals. Theory, Culture \& Society, vol. 10. no. 3. pp. 69-80.

McInnis, C. (2010). Traditions of academic professionalism and shifting academic identities. In. Whitchurch, C., \& Gordon, G. (Eds.). Academic and Professional Identities in Higher Education: The Challenges of a Diversifying Workforce, Abingdon: Routledge, pp. 147165.

Naidoo, R. (2005). Universities in the marketplace: The distortion of teaching and research. In. Barnett, R. (Ed.). Reshaping the University: New Relationships between Research, Scholarship and Teaching. Maidenhead, UK: Open University Press/McGraw-Hill, pp. 27-36.

Neave, G. (2009). The academic estate revisited: Reflections on academics'rapid progress from Capitoline Hill to the Tarpeian Rock. In. Enders, J., De Weert, E., \& de Weert, E. (Eds.). The Changing Face of Academic Life: Analytical and Comparative Perspectives. New York, NY: Springer. pp. 27-36.

Oross D. (2013). Civil és közéleti aktivitás. In. Székely L. (Ed.). Magyar Ifjúság 2012. Tanulmánykötet. Budapest: Kutatópont, pp. 283-330.

Panton, J. (2005). What are Universities for? Universities, Knowledge and Intellectuals. In. Cummings, D. (Ed.). The Changing Role of the Public Intellectuals. London, UK: Routledge, pp. 139-156.

Peterson, R. A. \& Kern, R. M. (1996). Changing highbrow taste: From snob to omnivore. American Sociological Review, vol. 61. 900-907. 


\section{iorhs}

4th International Conference On Research In

HUMANITIES \& SOCIAL SCIENCES

Pike, G. R. and Kuh, G. D. (2005): First and second generation college students - A comparison of their engagement and intellectual development. The Journal of Higher Education, vol. 76. no. 3. pp. 276-300.

Reuben, J. A. (1996). The Making of the Modern University: Intellectual Transformation and the Marginalization of Morality. Chicago, IL: University of Chicago Press.

Szabó I. (1990). A megtanulhatatlan ember. Társadalomtudományi Közlemények, vol. 20. no. 1-2. pp. 129-158.

Scott, P. (2005). Divergence or convergence? The links between teaching and research in mass higher education. In. Barnett, R. (Ed.). Reshaping the University: New Relationships between Research, Scholarship and Teaching. Maidenhead, UK: Open University Press/McGraw-Hill, pp. 53-66.

Veroszta Zs. (2010). Felsőoktatási értékek - hallgatói szemmel. Thesis. Budapest, HU: Corvinus University of Budapest. Sociological Doctoral School.

White, J. (2009). Scholarly identity. In. Fitzgerald, T. \& White, J. \& Gunter, M. H. (Eds.). Hard labour? Academic Work and the Changing Landscape of Higher Education. Bingley, UK: Emerald Groups, pp. 65-85.

Weidman, J.C. (2006). Socialization of Students of Higher Education: Organizational Perspectives. In: Clifton, C.C. and Ronald, C.S. (Eds). The Sage Handbook for Research in Education: Engaging Ideas and Enriching Inquiry. Thousand Oaks, CA: SAGE, pp. 253-262. 